\title{
TEORETYCZNE PODSTAWY WYCHOWANIA PAŃSTWOWEGO W POLSCE OKRESU MIĘDZYWOJENNEGO (ZARYS PROBLEMATYKI)
}

\begin{abstract}
Streszczenie: Artykuł podejmuje zagadnienie teoretycznych podstaw wychowania państwowego w Drugiej Rzeczypospolitej. Przedstawia zarys koncepcji wychowania państwowego Kazimierza Sośnickiego, Zygmunta Mysłakowskiego i Jana Stanisława Bystronia. Zagadnienie wychowania państwowego K. Sośnicki charakteryzował ze stanowiska pedagogiki socjologicznej oraz filozofii państwa i prawa. Tworząc ponadideologiczną teorię wychowania państwowego, uporządkował podstawowe pojęcia, wyeksponował specyficzne właściwości wychowania państwowego. Centralnym zagadnieniem swojej teorii uczynił kategorię etosu państwowego. Znaczny wkład w tworzenie teoretycznych podstaw wychowania państwowego stanowiły prace Zygmunta Mysłakowskiego. Rozumiejąc państwo jako formację socjologiczną i kulturową, punktem wyjścia do rozważań nad wychowaniem państwowym i narodowym uczynił pojęcie „mitu”. Dążył do ukształtowania pozytywnego stosunku społeczeństwa wobec państwa. Teoretyczną podstawę wychowania państwowego stanowiły również prace Jana Stanisława Bystronia, który prezentował stanowisko socjologiczne. Wychowanie państwowe łączył z wychowaniem społecznym, pogłębieniem kultury społecznej, rozszerzeniem treści i zakresu stosunków społecznych, rozwijaniem współdziałania.
\end{abstract}

Słowa kluczowe: wychowanie państwowe; Kazimierz Sośnicki; Zygmunt Mysłakowski; Jan Stanisław Bystroń; etos państwowy; historia wychowania.

\section{Wstęp}

Ideologia wychowawcza sanacji, nazywana wychowaniem państwowym lub obywatelsko-państwowym, doczekała się już wielu opracowań naukowych (Araszkiewicz 1976, 1978, 1982; Bartnicka 1972; Jakubiak 1994, 1999, 2003; Magiera 2003; Malinowski 2015; Wojtas 1999). Nie wchodząc w szczegóły, można stwierdzić, że lata 1926-1932 były okresem zmiany orientacji wychowania w kierunku wychowania państwowego, wyrastającego z założeń ideologicznych sanacji. Jak pisze Krzysztof Jakubiak, wychowanie państwowe zostało wypracowane dopiero po 1928 roku, a u jego „podstaw 
leżały przede wszystkim wymogi sytuacji politycznej, w jakiej znalazł się obóz piłsudczykowski i cała ówczesna Polska, oraz tradycje, doświadczenia historyczne, uwarunkowania społeczne i pryncypia ideologiczne piłsudczyków" (Jakubiak 1994, s. 64). Ideologia wychowania państwowego i funkcjonujący na jej fundamencie system oświatowo-wychowawczy dążyły do integracji wielonarodowej i wielokulturowej Polski, w oparciu o wartość nadrzędną, którą uczyniono państwo i której podporządkowano wartość narodu. Z tej wartości nadrzędnej wyrastały inne cechy konstytutywne ideologii sanacji: idea uspołecznienia państwa; idea solidaryzmu społecznego; odpowiedni stosunek jednostki do państwa; koncepcja elity społecznej; kult pracy oraz mocarstwowość Polski i jej misja dziejowa na Wschodzie, które znalazły odzwierciedlenie w wychowaniu państwowym (Faryś 1991; Jakubiak 1994).

Ideał wychowawczy, noszący nazwę pracownik-bojownik, sformułowany W 1929 roku przez Sławomira Czerwińskiego (Czerwiński 1929; Król 2016) ${ }^{1}$, doprowadził do bogatej dyskusji organizatorów szkolnictwa, teoretyków i praktyków, znajdującej wyraz w prasie i publikacjach zwartych. W latach 1932-1935 zostały opracowane teoretyczne podstawy ideologii wychowawczej sanacji w dziedzinach takich jak: socjologia, filozofia, kultura i psychologia. Całościowa reforma oświaty dokonana na mocy Ustawy z 11 marca 1932 roku o ustroju szkolnictwa, obejmująca zmiany strukturalne, organizacyjne i programowe (Hejnicka-Bezwińska 2015, s. 68, 74) doprowadziła do systemowej realizacji ideologii wychowawczej sanacji. Lata 1937-1939 były okresem półoficjalnego odwrotu sanacji od koncepcji wychowania państwowego i poszukiwania nowych tendencji wychowawczych.

Celem artykułu jest ukazanie zarysu problematyki teoretycznych podstaw wychowania państwowego. Wprowadzenie w życie „ustaw jędrzejewiczowskich” ujawniło słabości teoretyczne wychowania państwowego, które można było dostrzec m.in. w wystąpieniu J. Jędrzejewicza (Jędrzejewicz 1932, s. 64) i Hanny Pohoskiej (Pohoska 1932, s. 67-70) na zjeździe zrębowców 1 listopada 1932 roku. Słabości te stały się bodźcem do dalszych poszukiwań, których efektem były pogłębione naukowo prace Kazimierza Sośnickiego, Zygmunta Mysłakowskiego i Jana Stanisława Bystronia, posiadające obiektywny, badawczy charakter i stanowiące teoretyczną podbudowę doktryny wychowawczej sanacji ${ }^{2}$. Dlatego prace te stały się przedmiotem analizy niniejszego artykułu.

1 Intencją S. Czerwińskiego było „wychować ludzi, którzy z naszej ziemi wyrośli, naszym polskim służyliby celom i którzy byliby obywatelami cywilizowanego świata przez to i dlatego, że są dobrymi obywatelami Polski” (Czerwiński 1934, s. 75). Joanna Król, komentując te słowa, napisała: „Myśl tę, zawierającą głęboką troskę o kondycję młodego pokolenia, można zarazem potraktować jako motto działania dla obecnych i przyszłych twórców polskiej edukacji. Łączy ona bowiem $\mathrm{z}$ jednej strony przywiązanie do tradycji, a $\mathrm{z}$ drugiej przekonanie o silnej pozycji Rzeczypospolitej, której obywatele mogą bez kompleksów współuczestniczyć w tworzeniu kultury państw europejskich" (Król 2012, s. 132).

2 Poza wymienionymi uczonymi była cała plejada osób mających większy lub mniejszy udział w rozwijaniu teoretycznych podstaw ideologii wychowawczej sanacji i wskazujących na metody jej 


\section{Koncepcja wychowania państwowego Kazimierza Sośnickiego (1883-1976)}

Refleksję z zakresu teorii wychowania państwowego w latach międzywojennych najpełniej rozwinął Kazimierz Sośnicki, którego można uznać za głównego teoretyka wychowania państwowego. Jej zalążkiem był wygłoszony w maju 1928 roku na dorocznym zjeździe Związku Nauczycielstwa Szkół Średnich we Lwowie wykład pt. „Państwo a szkoła”, w którym autor starał się zwrócić uwagę na konieczność wprowadzenia wychowania państwowego do instytucjonalnego procesu kształcenia i wychowania. Wykład ten K. Sośnicki rozwinął na zjeździe autorów podręczników szkolnych, zorganizowanym z inicjatywy wydawnictwa „Książnica-Atlas” w listopadzie 1931 roku. W tych wystąpieniach, jak i w publikowanej dwa lata później książce stwierdził, że podstawy wychowania państwowego omawia w oderwaniu od konkretnego państwa, niezależnie od epoki i terytorium (Sośnicki 1933, s. 8). Jego celem było opracowanie ogólnych podstaw wychowania państwowego, dlatego świadomie unikał wiązania go z życiem i potrzebami konkretnego państwa ${ }^{3}$. Dążył do uporządkowania dyskusji wokół tej problematyki poprzez ustalenie podstawowych terminów, czego dokonał i tym samym umożliwił odróżnienie wychowania moralnego od wychowania społecznego czy państwowego. Dyskusja ukazała wzajemne relacje między tymi pojęciami oraz wyeksponowała specyficzne cechy wychowania państwowego.

Zagadnienie wychowania państwowego autor scharakteryzował ze stanowiska pedagogiki socjologicznej, uwzględniając wyniki badań przeprowadzonych na gruncie filozofii państwa i prawa. Jego poglądy kształtowały się głównie pod wpływem filozofii niemieckiej i opartej na niej teorii pedagogicznej, zwłaszcza Georga Kerschensteinera. K. Sośnicki wyszedł z założenia, że wychowanie państwowe jest ogólną ideą wiążącą szczegółowe, często sprzeczne cele wychowania, występujące w pedagogice na początku XX wieku. „Cechę państwowości - pisał - coraz silniej wysuwa się jako wspólny łącznik poszczególnych i w różnych wypadkach odmiennych celów wychowania; ma je ona zabarwić na jeden ton" (Sośnicki 1933, s. 43). Z mnogości celów wychowania, charakterystycznych dla ówczesnej pedagogiki, K. Sośnicki wyróżnił dwa kierunki, które je określały: pozytywistyczny lub pragmatyczno-realistyczny oraz indywidualistyczny. Podsumowując obydwa kierunki, opowiedział się za pierwszym z nich, ponieważ zapewniał on pomyślność

praktycznej realizacji, do których można zaliczyć: Waleriana Adamskiego, Józefa Chałasińskiego, Ludwika Chmaja, Sławomira Czerwińskiego, Włodzimierza Gałeckiego, Aleksandra Hertza, Stanisława Łempickiego, Józefa Mirskiego, Franciszka Mitka, Janusza Jędrzejewicza, Władysławę Hoszowską, Jerzego Ostrowskiego, Hannę Pohoską, Irenę Posseltównę, Franciszka Sadowskiego, Adama Skwarczyńskiego, Mieczysława Ziemnowicza, Franciszka Zycha i innych.

3 Halina Gajdamowicz zwraca uwagę na postawę naukową K. Sośnickiego, która charakteryzuje się analizą problemu, jakim było wychowanie państwowe, z punktu widzenia pedagogiki opisowej, a nie normatywnej. Podkreśla także znaczenie metody badawczej stosowanej przez K. Sośnickiego. Jest nią analiza formalna pojęć (Gajdamowicz 1991, s. 94-95). 
bytu materialnego, zdobycie kultury umysłowej oraz własną doskonałość człowieka. Poza tym pozytywistyczny kierunek wyodrębniania celów był związany $\mathrm{z}$ konkretnymi realiami i potrzebami życia, co stanowiło jego zaletę.

Zdaniem K. Sośnickiego, wyrazem niezgodności celów oraz sprzeczności interesów i dążeń poszczególnych jednostek były kolizje, konflikty wynikające ze wzajemnego stosunku jednostki i społeczeństwa. Główną potrzebą życia stało się więc ich rozwiązywanie. Źródła kolizji tkwiły w indywidualności osobowości ludzkiej, a zwłaszcza w czynniku subiektywizmu i wolności, który zachodzi w całości stosunków społecznych. K. Sośnicki, rozważając różne typy związków zachodzących między ludźmi (jednostkowe, jednostka a grupa, międzygrupowe), przyjął za podstawę rozwiązywania problemów, wynikających ze wzajemnego stosunku jednostki i społeczeństwa, socjologiczne pojęcie etosu. Stwierdził, że dzięki rozwiązywaniu kolizji powstałych wskutek współżycia z ludźmi wychowanie człowieka podlega pewnym prawidłowościom, normom, zasadom, które regulują stosunek jednostki do innych osób. „Zbiór zasad, który kieruje powstawaniem, przebiegiem i rozwiązywaniem kolizji" nazwał K. Sośnicki etosem (Sośnicki 1933, s. 58). Jego zdaniem etos ma pozytywny charakter, mimo że jego źródłem są kolizje. Nie jest zwykłym zbiorem zasad, posiada bowiem strukturalną budowę. W związku z pojmowaniem etosu jako systemu zasad kierujących kolizjami K. Sośnicki zauważył jego dwie właściwości: cechę powinności (czynnik intelektualny) i cechę wartości (czynnik emocjonalny). Zatem normy etosu żądają od człowieka dostosowania jego postępowania do wymagań etosu, ich zachowanie natomiast zależne jest od emocjonalności i dzięki temu wpływa na postępowanie jednostki.

Wychodząc z założeń socjologicznych, K. Sośnicki wychowanie ujmował w kategoriach społecznych, definiując je jako dążenie „do wytworzenia lub ustalenia pewnego sposobu zachowania się wobec kolizji społecznych” (Sośnicki 1933, s. 57). Głównym celem wychowania powinno być nie tyle przygotowanie do rozwiązywania konfliktów, ile przygotowanie człowieka do współdziałania i współżycia $\mathrm{z}$ innymi ludźmi. Naczelnym celem, z którego wynikają szczegółowe cele, było więc wychowanie do etosu. Najogólniej ujął te cele K. Sośnicki, dzieląc je na trzy grupy: wychowanie powinno dążyć do wytworzenia i utrwalenia w wychowankach pewnego etosu, czyli do uwewnętrzniania zasad etosu, ich rozumienia, przeżywania; zasady etosu powinny włączyć się w strukturę psychiczną wychowanka i odpowiednio ją przekształcić; wychowanie powinno stworzyć możliwości rozwoju etosu, którym kieruje się jednostka.

Zdaniem K. Sośnickiego, wychowaniu do etosu i rozwiązywaniu kolizji służą następujące rodzaje etosów: moralny, grupowy i państwowy. Sośnicki dokonał charakterystyki wymienionych wyżej trzech rodzajów etosów i rozpatrzył wszelkie możliwe stosunki różnych etosów wobec siebie. Dopiero na tej podstawie opracował problematykę wychowania państwowego. Etos moralny, który reguluje stosunek jednostki do jednostki, polega na dostrzeżeniu w drugim człowieku takiej samej natury ludzkiej, jaką on w sobie przeżywa. Na tej podstawie, budując w swoich 
myślach ideał człowieczeństwa, człowiek dąży równocześnie do ogólnoludzkiego ideału moralnego. Zasady etosu moralnego obowiązują wszystkich ludzi i są równe dla wszystkich. Znajduje on sformułowanie w pewnych normach postępowania, mających charakter przymusu wewnętrznego (Sośnicki 1933, s. 94-108). Etos grupowy, zawierając się w pojęciu idealnego członka grupy, reguluje kolizje między członkami grupy lub między członkiem grupy a grupą. Etos ten wyraźnie dąży do sformułowania swoich zasad i posługuje się sankcjami empirycznymi, przyjmującymi charakter zewnętrzny. Zarysowanie właściwości etosu moralnego i grupowego było dla K. Sośnickiego punktem wyjścia do rozważań o państwie, jego istocie, funkcji i zadaniach oraz do charakterystyki etosu państwowego.

W rozumieniu K. Sośnickiego państwo stanowiło raczej zbiorowisko grup społecznych niż społeczeństwo, którego wyróżnikiem był fakt, że „obejmuje ludność osiadłą na pewnym określonym terytorium” (Sośnicki 1933, s. 133). Pojmowanie państwa w znaczeniu zbiorowiska grup społecznych stało się powodem różnorodnych konfliktów między obywatelami, a więc posiadało odrębny etos. Etos państwowy różnił się od innych typów etosów. Wyodrębnił go autor na podstawie przeglądu teorii państwa, w których dostrzegł trzy grupy: teorię socjologiczną, teorię metafizyczną i teorię jurydyczną. Mimo trudności w określeniu istoty państwa K. Sośnicki wyróżnił jego specyficzne właściwości ${ }^{4}$.

Te trzy typy etosów (moralny, grupowy, państwowy) mimo swej odrębności są zależne od siebie, wpływają na siebie i wzajemnie się przekształcają. Szczególną rolę $\mathrm{w}$ tym procesie odgrywa etos moralny, jako czynnik kontrolujący różne rodzaje etosów. Najważniejszy jest jednak etos państwowy, który w stosunku do innych typów etosów może przybrać dwie skrajne postaci: autokratyczną, gdy usiłuje je sobie podporządkować lub liberalistyczną, gdy pozwala im rozwijać się we własnej sferze życia. Ponieważ największą rolę w przeżywaniu kolizji odgrywa etos państwowy, tym samym pierwsze miejsce przysługuje wychowaniu państwowemu. Pełne wychowanie państwowe obejmuje przyswojenie i przeżycie etosu państwowego. Jest procesem złożonym, obejmującym intelektualną, emocjonalną i wolicjonalną stronę osobowości ludzkiej. Wychowanie państwowe rozumiał więc K. Sośnicki jako wbudowanie etosu państwa w życie duchowe jednostki i grup ludzkich. Jego istotą jest ukształtowanie w wychowanku dyspozycji do pełnego przeżywania etosu, jego zasad i kierowanie się nimi w życiu. Dyspozycje te nazwał K. Sośnicki usposobieniem państwowym. Przyswojenie etosu państwowego pozwala na wytworzenie

4 Wśród specyficznych właściwości państwa K. Sośnicki wyróżnił: 1) ludność osiadłą na określonym terytorium; 2) ustalony porządek prawny, obowiązujący całą ludność. Etos państwowy zawiera cztery składniki: a) dążność do utrzymania się bez zmian w pewnej ustalonej formie, b) wyłączność, czyli dążenie do podporządkowania sobie całości współżycia obywateli z uwzględnieniem faktu, że jedynym czynnikiem władczym jest państwo, c) wyraźnie sformułowane zasady i ich konkretność, d) ostatni składnik, to przymus zewnętrzny wraz ze swymi sankcjami, wymagający przestrzegania dostojeństwa i nienaruszalności państwa. 
usposobienia państwowego, z którym łączył K. Sośnicki sumienie państwowe i patriotyzm państwowy. Osiągnięcie formalnego celu wychowania państwowego, jakim było dążenie do wytworzenia sumienia i patriotyzmu państwowego, było możliwe wtedy, gdy na treść wychowania państwowego składało się poczucie odpowiedzialności, zdyscyplinowanie każdego człowieka, wola dla siły państwa, wierność dla narodu i ziemi ojczystej, poczucie praw i obowiązków związanych z pracą kulturalną (Sośnicki 1933, s. 229).

W opinii K. Sośnickiego teoretyczne rozważania nad zagadnieniem wychowania państwowego nasuwają wiele pytań i trudności niemożliwych do rozwiązania. Problematyczna była niemożność szczegółowego określenia treści i celów tego wychowania, co w praktyce mogło prowadzić do werbalizmu i frazeologii w wychowaniu. K. Sośnicki zdawał sobie sprawę również z tego, że niektóre właściwości etosu państwowego mogą grozić pewnym niebezpieczeństwem dla wychowania i prowadzić do błędów w praktyce wychowawczej. Dlatego wymienił następujące wady wychowania państwowego (Sośnicki 1933, s. 201-219; Nawroczyński 1937, S. 22) $)^{5}$ :

1. Dążąc do trwałości i wyłączności etosu państwowego, wychowanie państwowe może stać się procesem ograniczającym, ciasnym i jednostronnym, pozbawionym tendencji rozwoju i doskonalenia.

2. Zbytnie eksponowanie wyłączności etosu państwowego może spowodować opór wychowanków lub doprowadzić do zacieśnienia horyzontów myślowych młodzieży.

3. Zewnętrzność etosu państwowego może doprowadzić do ukształtowania powierzchownych cech osobowości, do jednostronności, statyczności i lęku przed zmianą.

4. Trudności w wychowaniu państwowym mogą również wynikać ze stanu rozwoju, w którym znajduje się etos państwa. Jeśli jest on zakończony, łatwo staje się dogmatem, charakteryzuje się sztywnością norm, formalizmem i zdominowaniem innych etosów.

\section{Teoretyczne podstawy wychowania państwowego Zygmunta Karola Mysłakowskiego (1890-1971)}

W latach 1931-1935 w sprawach wychowania państwowego wielokrotnie głos zabierał Zygmunt Karol Mysłakowski. Jego prace stanowiły znaczący wkład w tworzenie teoretycznych podstaw wychowania państwowego oraz były swoistego rodzaju polemiką nad kształtem tej doktryny pedagogicznej. Wykładnię swoich poglądów przedstawił w książce Państwo a wychowanie, która zawierała wcześniej

5 K. Bartnicka stwierdziła wręcz, że K. Sośnicki przestrzegał przed „wulgaryzacją zasad wychowania państwowego i jego absolutyzacją" (1972, s. 100). 
publikowane na łamach czasopism pedagogicznych rozprawy naukowe (m.in. Mysłakowski 1931a; 1931b).

Odrzuciwszy pogląd Hegla, zgodnie z którym państwo jest celem samym w sobie, swoistym absolutem oraz wszechobecnym celem i sensem wychowania, pisał: „Pozostawmy to teleologiczne pojęcie państwa, przez wielkie „P” na uboczu. Egzaltacja takiego gatunku, według mego zdania poniża człowieka” (Mysłakowski 1935, s. 116). Państwo pojmował jako polityczną organizację społeczeństwa, która powstaje jako czynnik siły, przymusu i hierarchii. Pisał, że utrwalenie i ugruntowanie państwa w społeczeństwie wymaga zbudowania w sercach i umysłach obywateli jak najszerszych podstaw moralnych, co oznaczało, że państwo musi dążyć do wychowania sobie społeczeństwa. Twierdził, że państwo, pomimo różnych zastrzeżeń, jest niezbędnym narzędziem uspołecznienia jednostki. Był przekonany, że jest ono dogodnym miejscem dla tworzenia różnych mniejszych struktur społecznych i organizacyjnych oraz akceptowanych i przeżywanych wartości kultury. Wyrażał opinię, że w dziedzinie kultury szkodliwa jest dla społeczeństwa całkowita wszechwładza państwa, jak i brak ingerencji czynnika państwowego. (Mysłakowski 1934, s. 11-14) .

Z. Mysłakowski przede wszystkim zajął się przeanalizowaniem stosunku jednostki do narodu i państwa. Przyjął założenie, że jednym z najważniejszych zagadnień wychowania jest wytworzenie żywego kontaktu z kulturą narodową. Jeżeli naród był więc pewną formą tradycji kulturowej, to państwo było wyrazem jej najbardziej realnego, aktualnego życia, stanowiąc formę politycznego istnienia zbiorowości, organizację narodu. „Naród bez państwa - pisał Z. Mysłakowski jest czymś wiodącym żywot połowiczny, brak mu najpotężniejszego narzędzia samourzeczywistnienia" (Mysłakowski 1935, s. 7).

Twierdził, że za wychowanie odpowiada zarówno naród, jak i państwo, ale każde wychowuje w innej sferze i w inny sposób. Punktem wyjścia do rozważań nad wychowaniem państwowym i narodowym uczynił pojęcie „mitu”, w którym zasadnicze znaczenie pełnią trzy czynniki: naród, ojczyzna, państwo. Naród wychowuje przez przekazywanie swego mitu kolejnym pokoleniom, przez przekształcenie ich życia duchowego na wzór własnego mitu. Mit narodowy podobnie jak inne mity jest „złożoną rzeczywistością duchową”, o charakterze strukturalnym, będącą „żywotnym skrótem wzruszeń, obrazów, pojęć i wierzeń” (Mysłakowski 1931a, s. 7). Uważał, że wartość mitu narodowego wyraża się głównie w tym, że jest on środkiem wyzwalającym tkwiące w psychice człowieka zdolności do tworzenia struktur ponadjednostkowych. Mit ma zdolności do tworzenia struktur ponadindywidualnych, uspołecznia ludzi w granicach grupy narodowej, ale także może prowadzić do nietolerancji względem tego, co obce. Autor określił pojęcie patriotyzmu (mit ojczyzny) jako przywiązanie do własnej ojczyzny, o ile nie łączy się z nim idea napaści na inne ojczyzny. Idea ojczyzny zawiera w sobie ideę odosobnienia. W przypadku niewłaściwego wykorzystania idei ojczyzny może dojść do ekspansji bądź nacjonalizmu. Patriotyzm przeciwstawił nacjonalizmowi, stanowiącemu chęć 
„wywyższania własnego narodowego ja ponad inne” (Mysłakowski 1935, s. 35-36). $\mathrm{Z}$ tych powodów oparcie wychowania tylko na micie narodowym mogło być zdaniem Z. Mysłakowskiego - niebezpieczne.

Biorąc pod uwagę doświadczenia historyczne narodu polskiego, stwierdzał, że poczucie państwowe Polaków było i jest niewystarczające. Z tego względu wychowanie państwowe w latach 30. XX wieku stało się aktem koniecznym, ponieważ „wychowanie do polskiej racji stanu nie jest przedmiotem błahym, za stare są polskie nawyki, z którymi trzeba walczyć; dusza narodu nie zmienia się łatwo" (Mysłakowski 1935, s. 46). Państwo polskie uważał nie tylko za organizację przymusu, ale narzędzie uspołecznienia, które: 1) nie krępuje rozwoju kultur mniejszości narodowych ; 2) jest zespołem ludzi całkowicie wolnych; 3) jest nastawione na rozwój (Mysłakowski 1935, s. 42-46).

Stosunek państwa i wychowania Z. Mysłakowski rozumiał dwojako: albo jako czynnik wychowania, i wtedy mówi się o wychowaniu przez państwo, albo państwo jako cel wychowania i wówczas mówi się o wychowaniu dla państwa. Autor stał na stanowisku, że państwo nie powinno być pojmowane jako cel sam w sobie, dlatego należy rozdzielić wychowanie państwowe od państwa utożsamianego z istotą moralną, posiadającą ludzką tendencję do ubóstwiania czy moralizowania. Zdaniem Z. Mysłakowskiego, państwo samo w sobie nie jest wartością; jest wartościowe, gdy realizuje wartości. Mając na względzie te uwagi, wychowanie państwowe w rozumieniu Z. Mysłakowskiego polega nie na „przyjęciu takiej czy innej doktryny politycznej, lecz na wyrobieniu pewnej odrębnej postawy psychicznej, na emocjonalizacji stosunku do państwa; na oparciu tego stosunku nie o chęć pasożytowania, lecz na przyjętym osobistym obowiązku, na właściwym, swobodnym ustosunkowaniu się do tradycji; na przyjęciu postawy prospektywnej" (Mysłakowski 1934, s. 123). Jego zdaniem, jeżeli obywatele mają żywić przywiązanie do państwa, to muszą w nim widzieć miejsce pełnego życia, narzędzie ochrony, organizatora pracy i egzystencji, a nade wszystkim czynnik kultury, ładu i uspołecznienia ${ }^{7}$.

6 Z. Mysłakowski był zwolennikiem racjonalnej równowagi interesów narodowościowych i odpowiedzialności obywatelskiej za stan państwa i jego rozwój bez naruszania interesów indywidualnych, społecznych i etnicznych. Trzeba zgodzić się z opinią K. Szmyda, który uważa, że Z. Mysłakowski „pozostawał zwolennikiem konstruktywnego i w miarę harmonijnego rozwiązywania interesów jednostkowych, obywatelskich i ogólnopaństwowych" (Szmyd 1997, s. 156).

7 F. Gryń, recenzując książkę Z. Mysłakowskiego, pisał: „Dziełko to jakkolwiek niewielkie rozmiarami, olbrzymie jest treścią i głębią ujęcia zagadnienia, a ponieważ zawiera ono cały szereg myśli, jako wytworów rozpoczętej już pracy nad realizacją ideału wychowania państwowego, ponieważ omawia problem od strony naszych warunków, od strony filozofii życia i nieubłagalnych jego praw odwiecznych, ponieważ w sposób wysoce przystępny omawia najzawilsze nawet kwestie wychowawcze, dlatego warto by nie tylko przestudiowało je całe nauczycielstwo polskie, ale by stało się ono przedmiotem żywej dyskusji w oparciu o realne warunki środowiskowe naszej pracy" (Gryń 1935/1936, s. 29-30). 


\section{Koncepcja wychowania państwowego Jana Stanisława Bystronia (1892-1964)}

Teoretyczną podbudowę dla wychowania państwowego stanowiły również prace Jana Stanisława Bystronia, który zagadnienie to potraktował - podobnie jak K. Sośnicki i Z. Mysłakowski - w ujęciu socjologicznym. Pracę pisarską w duchu wychowania państwowego zapoczątkował jeszcze w 1930 roku, wydając książkę Szkoła $i$ społeczeństwo, a następnie snuł refleksje o wychowaniu państwowym w szkicach Uspołecznienie szkoły i w książce Szkoła jako zjawisko społeczne oraz w różnych artykułach (Bystroń 1933a; Bystroń 1934).

J. S. Bystroń sprzeciwiał się traktowaniu problemu wychowania państwowego jako celu samego w sobie. Na podstawie rozważań na temat definicji państwa wysunął następujący wniosek: jeżeli wychowanie ma być istotnie wychowaniem państwowym, to musi dbać o „rozszerzenie i pogłębienie twórczości jednostek w formach umożliwiających koordynację ich wysiłków twórczych" (Bystroń 1933c, s. 104). Tak pojmowane wychowanie państwowe nie różni się zasadniczo od wychowania społecznego, ponieważ jedno i drugie uczy współdziałania, pogłębia stosunki społeczne, rozszerza sfery intelektualne i emocjonalne człowieka w odniesieniu do państwa. Co nie oznaczało, że wychowanie społeczne miało to samo znaczenie jak państwowe. J. S. Bystroń przyznawał, że przeobrażenia współczesnego mu życia są tak skomplikowane, że koniecznością stało się opanowanie procesów społecznych. Pisał, że państwo polskie jest nie tyle organizacją policyjną, znaną z okresu zaborów, ile organizacją społeczną. W związku z tym cele wychowania państwowego w najszerszym ujęciu obejmowały „przygotowanie do samodzielnego wysiłku w jakimkolwiek terenie pracy społecznej, skoordynowanej z działalnością państwa” (Bystroń 1930).

Inaczej mówiąc, istotę wychowania państwowego J. S. Bystroń widział w rozszerzeniu kultury społecznej, polegającej na pogłębieniu treści stosunków społecznych, wiążących jednostki oraz rozbudowaniu ich zakresu. Uspołecznienie wiązał ze współdziałaniem, czyli logicznym podziałem różnorodnych czynności pomiędzy jednostki, które włączało wychowanków w systematycznie zorganizowaną pracę nad tworzeniem państwa (Bystroń 1933a, s. 58-76). Człowiekiem uspołecznionym nazwał „jednostkę, mającą poczucie swojej wartości, zdolną do samodzielności i inicjatywy, wdrożoną do współżycia $\mathrm{z}$ innymi, umiejącą, zależnie od warunków rozkazywać lub słuchać" (Bystroń 1933a, s. 35).

Według J. S. Bystronia, wychowanie państwowe, o ile rzeczywiście miało prowadzić do celu, powinno charakteryzować się aktywnością i twórczością wychowanków, obejmować całokształt pracy szkolnej, być pozbawione tresury, schematyzmu czy bierności. Jego zdaniem oprócz pracy nad podnoszeniem kultury stosunków społecznych, która miała polegać na twórczej współpracy nauczyciela i ucznia, w skład pojęcia wychowania społecznego (państwowego) wchodziły jeszcze dwa czynniki: przeżycie emocjonalne, czyli rozwijanie uczuć społecznych oraz kształcenie intelektualne, czyli zgłębianie wiadomości o życiu społecznym. J. S. Bystroń wyjaśniał, że wychowanie państwowe nie jest przedmiotem nauki, nie można go 
wprowadzić do programu rozporządzeniem ministerialnym, nie jest też sztywnym zbiorem informacji, które nauczyciel na lekcji powtarza i stara się uczniom przyswoić w sposób wierny i bierny. Twierdził, że wychowaniu państwowemu szkodzi patos i frazeologia (Bystroń 1933b, s. 6-14; Sierakowski 2009) ${ }^{8}$.

\section{Wnioski}

Dokonując próby podsumowania podjętych rozważań, można stwierdzić, że praca Kazimierza Sośnickiego była w Polsce pierwszym dziełem uzasadniającym wychowanie państwowe w obrębie filozofii państwa. Odznaczała się szerokością spojrzenia, krytycyzmem, spójnością merytoryczną i metodologiczną, chociaż jest ogólna i odległa od życia polskiego Drugiej Rzeczypospolitej. Wprowadziła pojęciowy ład w problematykę, którą z konieczności w tym okresie musiał interesować się każdy nauczyciel (Nalaskowski 1994, s. 40). Teoria wychowania państwowego K. Sośnickiego jest ponadczasowym i ponadideologicznym zagadnieniem dotyczącym relacji między wychowaniem a polityką, podejmowanym również w pierwszych dekadach XXI wieku (Półtórzycki 2003; Wesołowska 2003; Siemieniecka 2009; Kamiński 2014, s. 131-140).

Poglądy Z. Mysłakowskiego z uwagi na to, że kształtowały się w różnym czasie, nie przedstawiają spójnego systemu pedagogicznego, raczej widać w nich nakładanie się kierunku socjologicznego i kulturowego, choćby w rozumieniu terminu państwa jako formacji społecznej i kulturowej. Aczkolwiek są zgodne z ideologią obozu sanacji i zagadnienia wychowania państwowego ujmują bliżej międzywojennej rzeczywistości w stosunku do ogólnej teorii wychowania państwowego K. Sośnickiego, to jednak cechuje je wysoki poziom naukowości oraz respektowanie praw mniejszości narodowych. Ideę przewodnią w jego poglądach - potrzebę kształtowania w społeczeństwie polskim pozytywnego stosunku do państwa należy uznać za wartościową. Ta myśl była wcześniej także reprezentowana przez J. S. Bystronia i K. Sośnickiego. Poglądy Z. Mysłakowskiego pod wieloma względami upodabniały się do poglądów K. Sośnickiego, ponieważ mit pełnił podobne zadania co etos - tłumaczył przyczyny niepowodzeń człowieka, doszukując się ich źródeł tkwiących w indywidualności natury ludzkiej. J. S. Bystroń wychowanie państwowe wiązał z pogłębieniem i rozszerzeniem stosunków społecznych, z procesem uspołecznienia opartym na współdziałaniu w tworzeniu i rozwijaniu państwa.

Zarówno K. Sośnicki, jak i Z. Mysłakowski oraz J. S. Bystroń dostrzegali wiele niedomagań w teorii i praktyce ideologii wychowawczej sanacji. Nie występowali przeciwko założeniom wychowania państwowego, lecz przeciwko usztywnianiu zasad ideologicznych, fetyszyzacji pojęcia państwa i innych nieprawidłowościach, które mogą stanowić przedmiot rozważań w innych tekstach naukowych.

8 Poglądy teoretyczne J. S. Bystronia zaprezentowane zostały na łamach „Szkoły” przez Kingę Szymborską w artykule zatytułowanym Wychowanie państwowe („Szkoła” 1934, z. 7-8, s. 152-153). 


\section{Bibliografia}

Araszkiewicz F. W. (1976). Geneza ideałów wychowawczych Drugiej Rzeczypospolitej. „Rozprawy z Dziejów Oświaty”, t. 19, s. 143-174.

Araszkiewicz F. W. (1978). Ideały wychowawcze Drugiej Rzeczypospolitej. Warszawa: Państwowe Wydawnictwo Naukowe.

Araszkiewicz F. W. (1982). Teleologia pedagogiczna Drugiej Rzeczypospolitej. Wybrane zagadnienia. „Zeszyty Naukowe Wydziału Humanistycznego Uniwersytetu Gdańskiego. Pedagogika, Historia wychowania”, nr 13, s. 36-41.

Bartnicka K. (1972). Wychowanie państwowe: do dyskusji nad problemami ideologii wychowawczej sanacji. „Rozprawy z Dziejów Oświaty”, t. 15, s. 61-132.

Bystroń J. S. (1933c). Wychowanie państwowe, Kultura Pedagogiczna 1933, z. 2, s. $97-111$.

Bystroń J. S. (1930). Źródła kultury i zagadnienie kultury ludowej. „Zrąb”, t. 2, S. $149-164$.

Bystroń J. S. (1933a). Uspołecznienie szkoły i inne szkice Warszawa: Wydawnictwo M. Arcta. Bystroń J. S. (1934). Szkoła jako zjawisko społeczne. Warszawa: Nasza Księgarnia (wydanie I).

Bystroń J. S. (1933b). Zagadnienie programu szkolnego. „Zrąb”, t. 16, s. 3-22.

Czerwiński S. (1929). O ideał wychowawczy szkoły polskiej. „Oświata i Wychowanie”, Z. 4, s. 341-358.

Czerwiński S. (1934). O nowy ideał wychowawczy. Warszawa: Wydawnictwo Towarzystwa Kultury i Oświaty.

Faryś J. (1991). Piłsudski i piłsudczycy. Z dziejów koncepcji polityczno-ustrojowej 1918-1939, Szczecin: Wydawnictwo Naukowe Uniwersytetu Szczecińskiego.

Gajdamowicz H. (1991). Teoria wychowania i nauczania Kazimierza Sośnickiego $w$ świetle założeń pedagogiki filozoficznej. Łódź: Wydawnictwo Uniwersytetu Łódzkiego.

Gryń F. (1935/1936), Sprawozdania. Dr Z. Mysłakowski, Państwo a wychowanie. „Praca Szkolna”, nr 1, s. 27-30.

Hejnicka-Bezwińska T. (2015). Praktyka edukacyjna w warunkach zmiany kulturowej. Warszawa: Wydawnictwo Naukowe PWN.

Jakubiak K. (1994). Wychowanie państwowe jako ideologia wychowawcza sanacji. Ksztattowanie i upowszechnienie w periodycznych wydawnictwach społeczno-kulturalnych i pedagogicznych. Bydgoszcz: Wydawnictwo Uczelniane WSP.

Jakubiak K. (1999). Idea wychowania obywatelskiego w polskiej myśli pedagogicznej przełomu XIX i XX wieku oraz Okresu Drugiej Rzeczypospolitej. W: Wychowanie a polityka. Między wychowaniem narodowym a państwowym. Wojdyła W. (red.). Toruń: Wydawnictwo Uniwersytetu im. Mikołaja Kopernika.

Jakubiak M. A. (2003). Ideologia wychowawcza sanacji. „Saeculum Christianum”, 10/1, s. 253-266. 
Jędrzejewicz J. (1932). Przemówienie Pana Ministra WRiOP Janusza Jędrzejewicza. „Zrąb”, t. 12, s. 64-65.

Kamiński K. (2014). Teoria wychowania państwowego Kazimierza Sośnickiego. „Przegląd Pedagogiczny” nr 1, s. 131-140.

Król J. (2012). Sławomir Czerwiński (1887-1931) - minister, polityk, pedagog. W: Wybrani twórcy i ich idee pedagogiczne w Drugiej Rzeczypospolitej (1918-1939). Andrukowicz W., Magiera E. (red.). Szczecin: Wydawnictwo Zapol.

Król J. (2016). Kontrowersje wokół ideału wychowania państwowego Sławomira Czerwińskiego (1885-1931). W: Sławomir Czerwiński i wychowanie państwowe. Gołdyn P. (red.). Kalisz: Książnica Pedagogiczna; Kaliskie Towarzystwo Przyjaciół Nauk.

Magiera E. (2002). Wychowanie państwowe w szkolnictwie powszechnym Drugiej Rzeczypospolitej. Szczecin: Wydawnictwo Naukowe Uniwersytetu Szczecińskiego.

Malinowski L. (2015). Wychowanie państwowe w Drugiej Rzeczypospolitej. Warszawa: Wydawnictwo APS.

Mysłakowski Z. (1931a). Wychowanie państwowe a narodowe, „Muzeum”, z. 1, s. 1-13. Mysłakowski Z. (1931b). Wychowanie państwowe a narodowe, „Muzeum” 1931, Z. 2, s. 65-75.

Mysłakowski Z. (1933). Znaczenie badań nad środowiskiem dla wychowania do państwowości. „Kultura Pedagogiczna”, z. 4-5, s. 407-417.

Mysłakowski Z. (1935). Państwo a wychowanie. Warszawa: Nasza Księgarnia.

Nalaskowski S. (1994). Pedagogika i dydaktyka w ujęciu Kazimierza Sośnickiego. Toruń: Wydawnictwo Adam Marszałek.

Nawroczyński B. (1937). Zagadnienie szkoły i państwa w naszej literaturze pedagogicznej lat ostatnich. „Muzeum” 1931, z. 1, s. 14-27.

Pohoska H. (1932). Ideowe podstawy wychowania państwowego. „Zrąb”, t. 12, s. 67-70. Półturzycki J. (2003). Kazimierz Sośnicki-człowiek i dzieło. W: Kazimierz Sośnicki twórca dydaktyki polskiej. Góralska R., Półturzycki J., Wesołowska E. A., Wojdyło W. (red.). Toruń-Płock: Wydawnictwo Uniwersytetu Mikołaja Kopernika, Novum.

Sadowski F. (1933). Szkoła a fetyszyzm państwowy. „Zrąb”, nr 16, s. 93-98.

Siemieniecka D. (2009). Wychowanie państwowe - wartość ponadczasowa czy przeżytek? W: Współczesne odniesienia edukacyjne do pedagogiki Kazimierza Sośnickiego. Siemieniecki B. (red.). Toruń: Wydawnictwo Adam Marszałek.

Sierakowski M. (2009). Koncepcja szkoły w myśli Jana S. Bystronia. „Nauczyciel i Szkoła", nr 1-2 (42-43), s. 123-131.

Sośnicki K. (1933). Podstawy wychowania państwowego. Lwów-Warszawa: Książnica-Atlas.

Sośnicki K. (1934b). Prostowanie „interpretacji”. „Zrąb” 1934, t. 17, s. 85-91. 
Szmyd K. (1997). Zygmunt Mysłakowski (189o-1971) - twórczość pedagogiczna i wkład do rozwoju nauk o wychowaniu. Rzeszów: Wydawnictwo Wyższej Szkoły Pedagogicznej.

Szymborska K. (1934). Wychowanie państwowe. „Szkoła”, z. 7-8, s. 152-153.

Wesołowska E. A. (2003). Wychowanie państwowe według Kazimierza Sośnickiego. W: Kazimierz Sośnicki - twórca dydaktyki polskiej. Góralska R., Półturzycki J., Wesołowska E. A., Wojdyło W. (red.). Toruń: Wydawnictwo Adam Marszałek.

Wojtas A. (1999). Proces syntezy koncepcji wychowania państwowego i narodowego wdwudziestoleciu międzywojennym. W: Wychowanie a polityka. Między wychowaniem narodowym a państwowym. Wojdyło W. (red.). Toruń: Wydawnictwo Uniwersytetu Mikołaja Kopernika.

\title{
THEORETICAL FOUNDATIONS OF STATE EDUCATION IN POLAND BETWEEN 1918 AND 1939 (AN OUTLINE OF THE PROBLEM)
}

\begin{abstract}
The article addresses an issue of theoretical foundations of state education in the Second Polish Republic. It presents the outline of the concept of state education proposed by Kazimierz Sośnicki, Zygmunt Mysłakowski and Juliusz Balicki. K. Sośnicki characterized the issue of state education from the position of sociological pedagogy and the philosophy of state and law. By creating more than an ideological theory of state education, he systematized the basic concepts and highlighted specific properties of state education. He made a category of state ethos the central point of his theory. A significant contribution to the creation of the theoretical foundations of state education was made by Zygmunt Mysłakowski. Understanding the state as a sociological and cultural formation, he made the concept of "myth" the starting point for reflections on state and national education. He strived to shape a positive attitude of society towards the state. The theoretical foundation of state education was also the work of Jan Stanisław Bystron, who presented the sociological standpoint. He combined state education with social education, with a deepening of social culture, an expansion of the content and scope of social relations, and a development of cooperation.
\end{abstract}

Keywords: state education; Kazimierz Sośnicki; Zygmunt Mysłakowski; Jan Stanisław Bystroń; state ethos; history of education.

Elżbieta Magiera - doktor habilitowana nauk społecznych, profesor Uniwersytetu Szczecińskiego w Katedrze Historii Wychowania Instytutu Pedagogiki US. Naukowo zajmuje się historią wychowania. Autorka wielu artykułów i rozdziałów w monografiach oraz książek: Wychowanie państwowe w szkolnictwie powszechnym Drugiej Rzeczypospolitej (2003), Andrzej Sobczak (1905-1979) - nauczyciel i księgarz (2005) oraz Spółdzielczość jako forma edukacji w szkolnictwie polskim Drugiej Rzeczypospolitej (1918-1939) (2011), a także redaktorka tomów wchodzących w skład serii pt. Z badań nad tradycją polskiej pedagogiki i innych pozycji. Adres korespondencyjny: Instytut Pedagogiki, Uniwersytet Szczeciński, ul. Ogińskiego 16/17, 71-431 Szczecin. Adres e-mailowy: elzbieta.magiera@usz.edu.pl. 